UDC 378.12:81'243

DOI https://doi.org/10.24919/2308-4863/39-1-49

\author{
Irina DIMOVA, \\ orcid.org/0000-0003-1687-2658 \\ Lecturer at the Department of English \\ Petro Mohyla Black Sea National University \\ (Mykolayiv,Ukraine) irina.dimova.scientist@gmail.com
}

\title{
TYPES OF CONTROL FOR CHECKING LAW FACULTY STUDENTS' SKILLS AND COMPETENCES
}

In today's world of integration, the problem of the quality of education, namely language communication, is acute.

We are looking for different assessment methods and technologies that will be in line with international standards. In order for Ukraine to be one of the technically, economically and culturally developed countries of the world, it is first necessary to modernize domestic education. the results of which are their state final certification and competitive selection for higher education and master's degree. Such conditions of final assessment require teachers to use more effective techniques and methods of control and assessment of knowledge, skills and abilities of students. Among such effective methods can be identified testing, which means the relevance of the selected research.

The main goal of all teachers of foreign languages is to teach their students as accurately and effectively as possible to speak a foreign language to be ready to communicate in any format and understand the interlocutor in various life situations.

At this time, teachers face a speech task and communicative motivation

In senior courses, the language experience of students acquired by them in the previous stages of language learning is systematized and generalized. Methods and types of educational activities are increasingly taking forms close to the real conditions of communication. Creative, project, group, interactive forms of student work are widely used. The content of education is differentiated according to the profile of study.

Test control is an effective form of control that ensures the effective implementation of all its functions in the process of learning any foreign language for professional purposes.

In this article we are going to study the effectiveness of test control and the peculiarities of its use in teaching a foreign language for professional purposes.

We also try to analyze the pros and cons of testing as a method of knowledge control; determine its forms and features in foreign language classes for professional purposes;

The subject of research - testing, as one of the forms of assessment and control of skills and abilities in English classes.

Key words: test, control, competence, method, effectiveness, learning process, technology.

Ірина ДИМОВА, orcid.org/0000-0003-1687-2658 старший викладач кафедри англійської мови

Чорноморського національного університету імені Петра Могили (Миколаїв, Україна) irina.dimova.scientist@gmail.com

\section{ЕФЕКТИВНІСТЬ ТЕСТОВОГО КОНТРОЛЮ ТА ОСОБЛИВОСТІ ЙОГО ВИКОРИСТАННЯ У НАВЧАННІ ІНОЗЕМНОЇ МОВИ СТУДЕНТІВ ЮРИДИЧНОГО ФАКУЛЬТЕТУ}

У сучасному світі інтеграції гостро стоїть проблема якості освіти, а саме мовного спілкування.

Ми шукаємо різні методи й технологї̈ оцінки, які відповідають міжнародним стандартам. Для того, щчоб Украӥна була однією з технічно, економічно й культурно розвинених краӥн світу, насамперед необхідно модернізувати вітчизняну освіту. результатами чого є державна підсумкова атестація та конкурсний відбір для здобуття вищої освіти й магістратури. Такі умови підсумкового оцінювання вимагають від викладачів використання ефективніших прийомів і методів контролю та оцінки знань, умінь $і$ навичок учнів. Серед таких ефективних методів можна виділити тестування, щзо означає доречність обраного дослідження.

Головна мета всіх викладачів іноземних мов - навчити свойх учнів якомога точніше й ефективніше розмовляти іноземною мовою, бути готовими до спілкування в будь-якому форматі й розуміння співрозмовника в різних життєвих ситуачіях.

Натепер перед викладачами стоїть мовленнєве завдання та комунікативна мотивація.

На старших курсах мовний досвід учнів, набутий ними на попередніх етапах вивчення мови, систематизується та узагальнюється. Методи й види навчальної діяльності все частіше набувають форм, близьких до реальних умов спілкування. Широко використовуються творчі, проєктні, групові, інтерактивні форми роботи студентів. Зміст освіти диферениійовано відповідно до профілю навчання. 
Тестовий контроль - це дійова форма контролю, яка забезпечує ефективне виконання всіх його функиій у проиесі вивчення будь-якої іноземної мови в професійних цілях.

У статті ми збираємося вивчити ефективність тестового контролю та особливості його використання під час викладання іноземної мови в професійних ичілях.

Ми також намагаємося проаналізувати плюси й мінуси тестування як методу контролю знань; визначити його форми й особливості на заняттях з іноземної мови з професійною метою.

Предмет дослідження - тестування як одна з форм оиінювання та контролю вмінь і навичок на уроках англійської мови.

За мету ми поставили дослідження ефективності тестового контролю та особливості його використання в навчанні іноземної мови за професійним спрямуванням.

Ключові слова: тест, контроль, компетентність, метод, ефективність, процес навчання, технологія.

Introduction. In today's world, the psychological and social demand of high school students is language communication, because learning a foreign language in a professional field is a very complex process that requires both an individual approach to each and more time to learn.

High school students have certain psychological characteristics that distinguish them from previous years. The thinking of a student majoring in "Law" acquires an emotional character, and intellectual activity acquires a special color associated with his self-determination and his desire to develop in the profession. Psychological features of student development are manifested in all aspects of his educational activities. During this period, it is important for the student not to learn individual facts or details, but to understand the essence, specific actions or general scheme of activity.

Presenting main material. Senior students with such a condition of learning a foreign language in a professional field have fewer study hours, study at the standard level and at the end must reach level B2 (Баранова, 2002: 13).

In this case, senior students have in-depth study of a foreign language in a professional field, it will cost more hours, teaching methods are used, taking into account the profiling, which deepens the level of knowledge to the level of B2. The information provided differs significantly from the usual basic course in its topics, which may include:

1) features of communicative behavior in different English-speaking countries;

2) linguistic / stylistic features of different genres of oral and written speech;

3) translation as a professionally-oriented means and type of speech activity;

4) the literature of the countries whose language is being studied;

5) information on the culture (theater, cinema, mass media, national traditions and customs, folk art, genres of contemporary art, including music, pop music, etc.) of the countries whose language is studied;

6) regional information;

7) information on the history of the country whose language is being studied, etc.
Thus, the main aspects of teaching a foreign language in a professional field are awareness of the psychological characteristics of age and the formation and development of language competence in them as the main problem of the language barrier.

The concepts of monitoring and evaluation of students are an integral part of successful education around the world, they are an important factor in the learning process in any subject, including foreign languages.

The concept of control has several meanings, including testing of knowledge and skills or observation of any educational activity. The control helps the teacher to determine (Гальскова, 2000: 150):

1) the degree of mastering the material;

2) gaps in knowledge on certain topics;

3) evaluate their work, find shortcomings in it and correct;

4) timely pay attention to misunderstanding of the material;

5) check the ability to apply the acquired knowledge;

6) check the completeness of knowledge, etc.

Translated from English the word itself "Test" means control or verification. Regarding the control of foreign language classes for professional purposes, there are such types as:

- speech control (which tests the skills of speech mechanisms and correctness and content of statements);

- reading and writing control checked in comprehension of the text and reading technique aloud, and writing - in the correctness of dictation, etc.);

- audition control (control of comprehension of the listened text).

In order to check the effectiveness of teaching, mastering the material, topics incomprehensible to students and their level of education - around the world use different methods of knowledge control and assessment.

In order to assess the level of student knowledge, two formats are usually used - the usual test and testing.

These two methods differ in many ways, but the most important are:

1. Time. 
Test takes more time to write and test than testing.

Testing is usually to choose the right one from several options, and the test may contain long detailed answers, which take much longer to write, justify and verify.

2. Objectivity.

Usually, the method of testing is more objective, because it is assessed purely by the result and the calculation of the correct answers, while the test of the teacher may take into account the unconscious attitude of the teacher to behavior, antipathies or sympathies to certain students.

Thus, the implementation of control in teaching a foreign language in a professional field is carried out by different methods, but testing is a more accurate method of testing student knowledge. The test is also a good element to reinforce the acquired knowledge.

Testing is one of the best methods to identify gaps in knowledge, because it is a collection of tasks that allow you to assess the level of knowledge in several topics at once.

It is also a more objective means of pedagogical assessment.

There are the following types of control over the study of a foreign language by professional orientation in higher education.

1. Preliminary control, which checks the initial level of training, ie the degree of mastery of a foreign language program in a professional field. Current control, ie control of skills acquired after passing some of the lexical and grammatical material. It is carried out periodically throughout the study process at the university.

2. Current or final control, which is usually carried out after studying a section or lesson of the textbook. The results of such control allow to adjust the further course of the educational process.

3. Final control, which is usually conducted after graduation during the semester during exams.

Oral control, or questioning, is the most common form of control of students' knowledge, skills and abilities. In such a survey, the teacher gets ample opportunities to study the individual characteristics of the student's learning material, identifying the most important qualities for each type of speech activity: speech reaction, language automation, situational speech.

As a rule, the control is carried out in the form of a conversation during which the teacher asks questions and waits for the student's answer. It also takes the form of a story or message from a student on a particular topic, as well as some explanation of an event or phenomenon.

The duration of the individual survey should not be more than four minutes. The frontal survey is usually associated with the repetition of previously passed or just passed the material. The questions and answers in such a survey should be short to include all students in the group. The specificity of written control of knowledge, skills and abilities in a foreign language in the professional field is its efficiency - at the same time the test covered all students.

With this control, it is easier to classify errors in students' written work.

Test control, unlike traditional surveys and written control, always involves some dimension. For this reason, the assessment is based on great objectivity and independence from the possible subjectivity of the teacher, when the assessment will be based to some extent on the impression of the teacher, his personal likes or dislikes in relation to one or another taught. Such control can serve as a good tool for diagnosing the difficulty of language material for students, as a measure of the effect of learning and as a way of predicting learning success or failure. However, formal control (for example, in the form of an intermediate test or final exam) is not the only type (Логвіна, 2012: 40).

Equally important is the informal (or ongoing) monitoring that is currently underway in class and when doing homework. It is also possible to use tests and evaluate how they are performed. However, the possibility of involving students in this process is practically not used. Experience has shown that experience can not only complement and refine a teacher's judgment of how learning takes place, but also significantly affect students' attitudes toward learning and formal control.

Fear of a test or exam is replaced by a sense of responsibility for own achievements, and thus the internal motivation of training grows. Formal control is designed to provide information on the achievement of learning objectives.

Tests and exams that implement formal control are designed, on the one hand, to assess how those who are taught are able to perform specific communicative tasks, i.e., how they speak the language being studied and, on the other hand, to assess the extent to which the course meets the objectives set in its development, ie whether it meets the needs of students as learners of the language and its users.

Intensive growth of interest in the systems of test control of knowledge in the domestic university science is justified by the fact that the traditional control system in the university is experiencing a crisis. The disadvantages of traditional methods are largely obvious. The simplicity and versatility of oral control is very attractive, but it is selective, does not allow to listen to all students and give each of them enough time. 
Exams, the most common of which are a good method of knowledge control, however, cannot guarantee compliance with the student's assessment of true knowledge of the subject, which he possesses. Limited exam time, poor comparability of results, different control conditions reduce the possibility of implementing a high level of knowledge by many students. As a result, in addition to traditional methods of control, test control of knowledge is increasingly coming into the higher education process.

Tests are now used at all stages of learning and are the most common form of control and self-control in higher education. Testing is one of the most technological forms of automated control with controlled quality parameters. Test control is possible in "paper" form, when students are given sheets of paper with printed tests, but it is really effective only

However, it is obvious that not all the necessary characteristics of learning material can be obtained by testing. For example, the ability to coherently, logically and conclusively express their thoughts, the ability to specify their answer with examples, knowledge of facts and some other characteristics of knowledge, skills and abilities can be diagnosed through testing. Of course, where knowledge and teaching material are structured and formalized more easily, such as in the natural sciences, it is easier to take test tasks.

It means that testing must be combined with other (traditional) forms and methods of testing knowledge. And only then it is possible to objectively establish the level of theoretical knowledge, intellectual skills, practical skills of students. There are different approaches to the classification of tests used for language learning: by purpose, object of testing, purpose, structure, form of execution, etc.

By purpose, there are:

1) tests to assess current performance;

2) thematic, designed to test knowledge of certain topics;

3) periodic or intermediate. They are used to assess knowledge for a certain period of time;

4) final, assessing the end result of learning;

5) prognostic, the purpose of which is to identify students' abilities to learn foreign languages;

6) professionals who determine the general level of language proficiency of various specialists;

7) those who test knowledge of language rules (grammar and vocabulary tests);

8) assess the level of speech activities in a foreign language (such tests test the knowledge of listening, speaking, reading and writing);

9) combined.

The following types of questions can be used to assess the level of students' knowledge in tests of any type:
1) closed questions such as "true - false";

2) closed multiple choice questions with one correct answer;

3) closed multiple choice questions with the possibility of choosing several correct answers;

4) open questions with a short answer;

5) open questions with a detailed answer;

6) questions with an alternative choice (for example: "Could you (lend, loan) me two dollars?");

7) questions with completion (for example: "The sun rises in the East and sets in the ...");

8) questions that involve action with groups (for example: "Exclude an extra word from the following series of words: shout, tell, call, notice");

9) questions that involve comparison (for example: "Highlight the antonyms in the following words ...").

Returning to the formal approach, it should be noted that tests and exams that implement formal control are designed, on the one hand, to assess how those who are taught are able to perform specific communicative tasks, ie how well they know the language being studied, and with another is to assess the extent to which the course meets the objectives set in its development.

There are four main types of tests that implement formal control, and the specific purpose of each. It is their special purpose (or main function) that distinguishes one type of test from another. However, each of them may pursue other tasks. Thus, the first three types of test can be aimed at identifying the weaknesses of students.

Actually, diagnostic tests should be used with extreme caution. It is necessary to strive to ensure that such tests do not have a negative impact on the learning process, because, as practice shows, they often create an atmosphere of tension and sometimes mistrust. Let's focus in more detail on the first three types of tests that allow for formal control.

1. Constituent tests are conducted before the start of training and perform at least three functions:

a) determining the level of foreign language proficiency of students;

b) diagnosing language defects (the test results should be considered from a constructive standpoint, namely - to use, for example, to determine the nature and content of a foreign language course in a professional field);

c) distribution of students in groups. It should be noted that the test is not the only means of diagnosing the needs of students in learning a foreign language for professional purposes, although it can provide information not only about what the student lacks, but also what potential can be used.

2 . Tests of success in studying a foreign language course in a professional field are familiar to the 
teacher to the greatest extent, because they are based on the research material, providing intermediate control that provides feedback necessary to optimize the learning process and improve the course.

3. Language proficiency tests are designed to implement the final control. These are usually tests related to the criterion. Their goal is to show how well students have learned to solve communicative problems in the language they are learning, what they need to continue learning at a higher level. A striking example of such tests is the IELTS (International English Language Testing System) exam, which assesses the ability of foreign students to study at a university in an English-speaking environment (Олейнікова, 2010: 10).

One of the main goals of education reforms is to ensure an appropriate, competent and modernized level of knowledge in foreign languages.

The main task of modern teachers is not only the presentation of language material, but to ensure students' language communication, the ability to apply the acquired knowledge in practice in any communication.

Testing in the process of learning English is an important indicator to identify the level of student achievement, their abilities, problems in understanding any topics, and so on.

Lingua didactic testing is most often used in foreign language teaching.

It is also a set of tasks prepared for certain requirements, which allows to identify the level of their linguistic and communicative competence in test participants and to evaluate the test results according to pre-derived criteria.

Among the main indicators of the quality of the didactic test are:

1. Validity is a characteristic of a test that shows what exactly determines the test and how effectively it does so. Validity of the test means its suitability for determining the level of mastery of certain foreign language speaking skills and abilities.

2. Reliability is a necessary condition for the validity of the test. The reliability of the test is determined by the stability of its function as a measuring instrument. A reliable test gives approximately the same results with each application.

3. Differential ability - a characteristic of the test, which indicates the ability of the test to identify successful and underachieved test subjects, ie to identify students with sufficient and insufficient levels of foreign language skills and abilities.

4. Practicality - a characteristic of the test, which determines:

a) the availability of test instructions and the content of test tasks; b) simplicity of the organization of carrying out of testing in various conditions;

c) simplicity of check of answers and definition of results and an estimation. Cost-effectiveness - a characteristic of the test, which provides a minimum amount of time, effort and money to prepare the test from planning to testing.

5. Cost-effectiveness - a characteristic of the test, which provides a minimum amount of time, effort and money to prepare the test from planning to testing.

Testing has many types and forms, among which may be as follows:

1. Multiple choice. Among the many options select the required;

2. Consistent choice. Read the text and sequentially put the required letter that corresponds to the specified events;

3. Multiple choice to fill in the gap in a sentence.

4. Alternative choice. Choose a sentence that matches the given picture;

5. Cross-selection. Fill in the blanks in the sentences of the text, the variants of which are indicated after the text.

6. Free choice. Identify the main idea of the text or color the picture according to the text.

Thus, the main distinguishing feature of the test is to provide quantitative information about the quality of learning. At the same time, it provides an opportunity to test a large amount of material studied in small portions and analyze the mastery of the material of most students.

Testing reveals the following levels of language proficiency:

- Elementary (elementary level) - basic skills English for communication on a narrow range of topics;

- Lower Intermediate - communication on interesting topics with a rather limited vocabulary of spoken English;

- Intermediate (middle level, occupying an intermediate level) provisions) - free communication on both abstract topics and maritime topics using professional terminology.

Conclusions. In the course of modernization of the educational process there is a change in the target settings, content and technology of education. The use of modern information technologies provides intensification and actualization of the educational process. Rapid informatization of modern society brings to the fore the problem of developing effective teaching methods, as well as improving the system of automated control and measurement of knowledge. Rapid and high-quality assessment of students' knowledge is an urgent problem of the educational process.

For any education system, the most important are objective quality control of knowledge and on this 
basis the construction of effective learning algorithms. One of the modern types of such control is testing.

Control as an integral part of the learning process is used when you want to establish how students use the target language, how advanced they are in learning it, or diagnose problems and provide them with the necessary.

Control is often associated with the assessment of various factors influencing the learning process: the goals stated in the program, course design, materials, methods of work of the teacher and the procedures of the control. It is one of the main sources of information about what happens in the learning process.

The purpose of control is to identify the level of knowledge acquisition by students at different stages of the learning process, determine the relevance of the identified level of planned knowledge and use the data to manage further learning.

Control differs from other types of perception in that it is a comparative perception. in the process of which the student's actions are compared with a certain standard. What is perceived for the purpose of control is called the object of control. These can be some rules of pronunciation, grammar rules, rules of reading or learning vocabulary, etc.

The main task of learning a foreign language in a professional direction is the ability to express their own thoughts in the language being learned and understand the language in this language other people. Thus, all aspects of speech communication are subject to control: listening, speaking, reading and writing.

\section{BIBLIOGRAPHY}

1. Баранова С. В. Актуальні проблеми методів навчання перекладу. Вісник Сумського держсавного університету. Серія: Філологічні науки. 2002. № 4 (37). С. 12-15.

2. Гальскова Н. Д. Современная методика обучения иностранным языкам. Москва : АРКТІ, 2000. 166 с.

3. Гривко А. В. Компоненти моніторингу для оцінки ключової комунікативної компетентності студентів. Анотовані результати дослідницької роботи Інституту педагогіки НАПН України за 2015 рік. Київ : Інститут педагогіки, 2015. C. 133-135.

4. Голуб Г. Б. Оцінка рівня сформованості ключових професійних компетентностей випускників УНП: підходи та процедури. Питання освіти. 2008. № 2. С. 161-185.

5. Загальноєвропейські рекомендації щодо мовної освіти : вивчення, викладання, оцінювання. Наукове українське видання доктора пед. наук, проф. С. Ю. Миколаїва. Київ : Ленвіт, 2003. 273 с.

6. Кук Л. О., Сергієнко В. П. Проєктування тестів. Курс лекцій : навчальний шлях. Луцьк, 2010. 182 с.

7. Логвина И. Инструменты формирующего оценивания в деятельности учителя-предметника : пособие для учителей.. Нарва, 2012. 48 с.

8. Олейникова Е. А.. Методика тестирования грамматики в процессе формирования профессиональной иноязычной коммуникативной компетенциифранцузский язык, неязыковой вуз : автореф. дисс. .... канд. пед. наук : 13.00.02 ; ГОУВПО «Орловский государственный университет». Москва, 2010. 20 с.

9. Черноватий Л. М. Методика викладання перекладу як спеціальність : підручник для студентів вищих закладів освіти за спеціальністю «Переклад». Вінниця : Нова книга, 2013. 236 с.

\section{REFERENCES}

1. Baranova S. V. Aktual'ni problemy metodiv navchannya perekladu. [Current problems of translation teaching methods] Visnyk Sums’koho derzhavnoho universytetu. Seriya: Filolohichni nauky. 2002. № 4 (37). S. 12-15. [in Ukrainian].

2. Hal'skova N. D. Sovremennaya metodyka obuchenyya ynostrannym yazykam. [Modern methods of teaching foreign languages] Moskva: ARKTI, 2000. 166 s. [in Russian].

3. Hryvko A. V. Komponenty monitorynhu dlya otsinky klyuchovoyi komunikatyvnoyi kompetentnosti studentiv. [Monitoring components for assessing students' key communicative competence] Anotovani rezul'taty doslidnyts'koyi roboty Instytutu pedahohiky NAPN Ukrayiny za 2015 rik. Kyiv: Instytut pedahohiky, 2015. 302 s. [in Ukrainian].

4. Holub H. B. Otsinka rivnya sformovanosti klyuchovykh profesiynykh kompetentnostey vypusknykiv UNP: pidkhody ta protsedury. [Assessment of UNP graduates key professional competencies: approaches and procedures] Pytannya osvity. № 2. 2008. 312 s. [in Ukrainian].

5. Zahal'noyevropeys'ki rekomendatsiyi shchodo movnoyi osvity: vyvchennya, vykladannya, otsinyuvannya. [European recommendations for language education: study, teaching, assessment] Nauka. vyd. ukr. vydannya doktora ped. Nauk, prof. S. YU. Mykolayiv. Kyyiv: Lenvit, 2003. 273 s. [in Ukrainian].

6. Proektuvannya testiv. Kurs lektsiy: [Test designing. Course of lectures:] navch. shlyakh. L. O. Kuk, V. P. Serhiyenko. Luts'k, 2010. 182 s. [in Ukrainian].

7. Lohvina I. Instrumenty formuyuchoho otsinyuvannya v diyal'nosti vchytelya-predmetnyka: posibnyk dlya vchyteliv. [Tools for formative assessment in the activities of the subject teacher: a guide for teachers] Narva, 2012. $48 \mathrm{~s}$. [in Ukrainian].

8. Oleynikova YE. A. Metodolohiya perevirky hramatyky $\mathrm{v}$ protsesi formuvannya profesiynoyi inshomovnoyi komunikatyvnoyi kompetentnosti: [Methodology of grammar testing in the process of professional foreign language communicative competence formation] avtoref. Dysertatsiya ... kand. ped. Nauk: 13.00 .02 [HOUVPO "Orlovs'kyy derzhavnyy universytet"] Moskva, 2010. 20 s.[in Ukrainian].

9. Chernovatyy L. M. Metodyka vykladannya perekladu yak spetsial'nist': [Methods of teaching translation as a specialty] pidruchnyk dlya studentiv. vyshcha osvita Osvita za spetsial'nistyu "Pereklad". Vinnytsya: Nova knyha, 2013. 236 s. [in Ukrainian]. 